\title{
Das \\ Territorium der Stadt Strassburg bis zur Mitte des 16. Jahrhunderts \\ (nebst einer Karte).
}

\author{
Von
}

Dr. phil. Ludwig Knobloch.

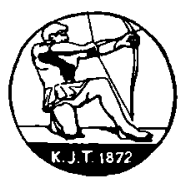

Straßburg

Verlag von Karl J. Trübner

1908. 
